S. BOŻENA SZEWCZUL WNO

Wydział Prawa Kanonicznego

Uniwersytetu Kardynała Stefana Wyszyńskiego w Warszawie

\title{
DEFINICJA PRAWNO-TEOLOGICZNA ŻYCIA KONSEKROWANEGO PRZEZ PROFESJĘ RAD EWANGELICZNYCH
}

Treść: Wprowadzenie. - 1. Terminologia: od stanu doskonałości do życia konsekrowanego. - 2. Potrzeba zdefiniowania życia konsekrowanego. - 3. Życie konsekrowane przez profesję rad ewangelicznych. - 4. Elementy teologiczne. - 4.1. Działanie Ducha Świętego. - 4.2. Dokładniejsze naśladowanie Chrystusa. - 4.3. Całkowite oddanie się umiłowanemu nade wszystko Bogu. - 4.4. Poświęcenie się z nowego i szczególnego tytułu dla chwały Boga, budowania Kościoła i zbawienia świata. - 4.5. Dążenie do świętości w służbie Królestwu Bożemu. - 4.6. Bycie w Kościele wyraźnym znakiem. 4.7. Zapowiadanie Królestwa Bożego. - 5. Elementy prawne. - 5.1. Stałość w obranej formie życia. - 5.2. Wolność wyboru życia konsekrowanego. - 5.3. Zobowiązanie się do życia radami ewangelicznymi przez śluby lub inne więzy. - 5.4. Szczególna łączność z Kościołem i jego tajemnicą. - 5.5. Kanoniczne erygowanie instytutów życia konsekrowanego. - 5.6. Przestrzeganie prawa własnego instytutu. - Zakończenie

\section{Wprowadzenie}

Ogłoszenie przez papieża Franciszka Roku Życia Konsekrowanego trwającego od 30 listopada 2015 r. (I Niedziela Adwentu) do 2 lutego 2016 r. (Święto Ofiarowania Pańskiego) skłania do zastanowienia się nad samym terminem życie konsekrowane, który pojawił się stosunkowo niedawno, a także nad jego znaczeniem. Mało pisze się na ten temat, podczas gdy określenie to nie jest chyba rozumiane w sposób pełny nawet przez same osoby konsekrowane. Niewiele z nich sięga 
do Kodeksu Prawa Kanonicznego Jana Pawła II z 1983 roku, gdzie, jak się wydaje, podano całościową definicję tego rodzaju życia w Kościele. Najczęściej bowiem życie konsekrowane wyjaśnia się jako szczególnie poświęcone (konsekrowane) Bogu. Tymczasem już sakrament chrztu, określany także mianem konsekracji chrzcielnej, poświęca Bogu życie każdego ochrzczonego, tak że staje się on alter Christi i jego życie jest prawdziwym życiem konsekrowanym. Również przez przyjęcie sakramentu święceń kapłańskich kapłan konsekruje się całkowicie Bogu ${ }^{1}$. O jaką więc konsekrację chodzi w przypadku tzw. osób konsekrowanych, kiedy ona się dokonuje i co tak bardzo wyróżnia osoby konsekrowane, że tworzą one odrębny stan w Kościele, aczkolwiek niehierarchiczny?

\section{Terminologia: od stanu doskonałości do życia konsekrowanego}

Przed Soborem Watykańskim II życie zakonne określano mianem stanu doskonałości (status perfectionis). Przez pojęcie stanu rozumiano stały sposób życia, który według prawa kanonicznego nazywano stanem prawnym obejmującym określoną grupę osób posiadających te same prawa i obowiązki. Rzeczownik doskonałość wskazywał na coś, co jest doskonałe, a więc nie wykazuje żadnych braków, i w porządku nadprzyrodzonym odnosił się do miłości i świętości rezerwowanej w tym wypadku dla zakonników, którzy przyjmują jako stały sposób życia dążenie do świętości, czyli doskonałej miłości. Trzeba w tym miejscu dodać, że w tradycji teologicznej i prawnej w odniesieniu do zakonników mówiło się o doskonałości nabywanej (perfectio acquirenda), nie zaś doskonałości posiadanej (perfectio acqusita), zarezerwowanej w tamtej epoce dla stanu biskupiego. Wierny, wchodząc do stanu zakonnego w wyniku złożenia profesji zakonnej, nie stawał się tym samym doskonały, lecz wyrażał pragnienie dążenia do

\footnotetext{
${ }^{1}$ J. F. CAStaño, Significato di vita consacrata. Studio comparativo tra il Vaticano II e il CIC'83, Angelicum 72(1995), s. 276-277.
} 
doskonałości² ${ }^{2}$ Stąd klasztor, życie zakonne pojmowano jako szkołę doskonałości, służby Panu, szkołę miłości i świętości ${ }^{3}$ Życie zakonne już samo w sobie dzięki profesji zakonnej służyło osiągnięciu miłości doskonałej, ponieważ zakonnicy zobowiązywali się do tego publicznie w odróżnieniu od laików, a ich ślubowanie rad ewangelicznych umożliwiało łatwiejsze jej zdobycie ${ }^{4}$. W 1947 roku papież Pius XII w konstytucji apostolskiej Provida Mater Ecclesia zaliczył do stanów doskonałości nabywanej także członków instytutów świeckich, którzy realizują swą konsekrację, żyjąc na sposób wiernych świeckich ${ }^{5}$.

Termin stan doskonałości, wskazujący na nabycie doskonałości dzięki obraniu życia w instytutach zakonnych lub świeckich i wyłączający tym samym inne możliwości dążenia do osiągnięcia świętości w Kościele katolickim, np. w przypadku wiernych świeckich, budził zastrzeżenia w czasie opracowywania dokumentów Concilium Vaticanum II $i$ stąd unikano go. Nie pojawiła się w nich jeszcze w sposób wyraźny nowa nazwa życie konsekrowane ${ }^{6}$. Dopiero w schematach

2 J.F. Castaño, Significato di vita consacrata..., s. 244-246; G. GHirlanda, Vita consacrata, Dizionario degli Istituti di Perfezione (odtąd DIP), vol. 10, Roma 2003, col. 351-359; A. PAssini, Professione di carità perfetta, Rivista delle Religiose 15(1966), s. $523-525$.

${ }^{3}$ Benedy kt z Nursji, Reguła, Prolog, (przekład A. Świderkówna), Tyniec 1997², s. 23-35; P. Beniamino della SS. Trinità, Vita religiosa e santità della Chiesa, w: AA.VV., La santità nella costituzione conciliare sulla Chiesa, Roma 1966, s. 182-183; Jan PAwe€ II, Posynodalna adhortacja apostolska o życiu konsekrowanym i jego misji w Kościele i świecie "Vita consecrata», nr 35, Warszawa-Ząbki 1996 (odtąd Vita consecrata).

${ }^{4}$ J.M. Lozano, La sequela di Cristo. Teologia storico-sistematica della vita consacrata, Milano 1981, s. 90.

${ }^{5}$ PIUs XII, Constitutio apostolica, De statibus canonicis institutisque saecularibus christianae perfectionis adquirendae, "Provida Mater Ecclesia». Lex peculiaris Institutorum saecularium, 2 februarii 1947, AAS 39(1947), s. 114-124; tekst polski: Święta Kongregacja dla ZaKonów I Instytutów ŚwIECKICH, Instytuty świeckie w wypowiedziach Magisterium Kościoła, Roma 1975, s. 13-30.

${ }^{6}$ Termin „stan doskonałości” pojawia się przypadkowo tylko w pierwszych dokumentach soborowych tj. konstytucji o świętej liturgii Sacrosanctum Concilium nr 98 i $101 \$ 1$ oraz w konstytucji dogmatycznej o Kościele Lumen gentium nr 45 używa się sformułowania „instytuty doskonałości”, natomiast „,̇ycie konsekrowane” 
przygotowawczych do KPK/1983, a następnie w odpowiednich kanonach Kodeksu, zastosowano dość długie określenie instytuty życia konsekrowanego przez profesje rad ewangelicznych ${ }^{7}$. Wskazuje ono jasno, że życie konsekrowane to podjęcie rad ewangelicznych przez złożenie profesji, która wprowadza do nowego stanu w Kościele stanu życia konsekrowanego. $Z$ biegiem czasu powszechnie przyjęła się skrócona wersja wyżej wspomnianej nazwy ograniczająca się jedynie do członu życie konsekrowane.

\section{Potrzeba zdefiniowania życia konsekrowanego}

Prawodawca kościelny, przejmując doktrynę Soboru Watykańskiego II dotyczącą życia według rad ewangelicznych oraz posoborowe doświadczenie przystosowanej do współczesności odnowy życia zakonnego, podjął się sformułowania w Kodeksie Prawa Kanonicznego z 1983 roku kompleksowej definicji życia konsekrowanego, mimo iż wszelkie definicje w prawie są niebezpieczne ${ }^{8}$. Do podjęcia takiej decyzji przyczyniła się zapewne zbyt daleko idąca „odnowa” życia zakonnego w niektórych krajach, poddająca w wątpliwość nie tylko niektóre jego fundamentalne zasady, ale nawet sam sens istnienia9 . Aby przybliżyć istotę życia konsekrowanego i zapobiec pojawiającym się nieporozumieniom, w pierwszym kanonie dotyczącym norm wspólnych wszystkim instytutom życia konsekrowanego KPK/1983 podano w ramach definicji zasadnicze elementy teologiczne i prawne

pojawia się tylko raz w dekrecie o przystosowanej do współczesności odnowie życia zakonnego Perfectae caritatis nr 1d; G. GHIRLAnda, Vita consacrata, DIP, vol. 10, Roma 2003, col. 551.

${ }^{7}$ KPK/1983, kan. 573; J.F. CAstaño, Significato di vita consacrata..., s. 252.

${ }^{8}$ D. 50,17,202: „Omnis definitio in iure civili periculosa est, parum est enim ut non subverti possit”. Por. L. De MAuri, Regulae iuris. Raccolta di 2000 regole del diritto, Milano $1971^{11}$, s. 192; J. ŚLIwA, La funzione stabilizzante della Chiesa nel processo di nascita degli IVC - CIC can. 573, Angelicum 85/1(2008), s. 107.

${ }^{9}$ Święta Kongregacja Zakonów i Instytutów Świeckich, Instrukcja o istotnych elementach nauczania Kościoła na temat życia konsekrowanego w zastosowaniu do instytutów oddających się pracy apostolskiej «The renewal of religious life», 2, 4, 5, w: Życie konsekrowane w dokumentach Kościoła. Od Vaticanum II do Ripartire da Cristo (red. K. Wójtowicz), Kraków 2003², s. 289-315. 
tego rodzaju życia. Elementy te zostały następnie doprecyzowane w kolejnych kanonach definiujących szczegółowiej instytuty zakonne, instytuty świeckie i stowarzyszenia życia apostolskiego oraz życie prowadzone w indywidualnych formach konsekracji, tj. życie pustelnicze i kanoniczny stan dziewic konsekrowanych ${ }^{10}$.

W dalszej części artykułu zostaną opisane najpierw elementy teologiczne, a następnie prawne składające się na pojęcie życia konsekrowanego. Przypomnienie ich wszystkich i krótkie omówienie w ramach jednego artykułu wydaje się użyteczne, gdyż i obecnie - 50 lat od wydania soborowego dekretu o przystosowanej do współczesności odnowie życia zakonnego Perfectae caritatis i 30 lat od promulgacji KPK/1983 - poszczególne aspekty życia konsekrowanego bywają poddawane $w$ wątpliwość, a nawet negowane. A trzeba zauważyć, że wymienione w KPK/1983 elementy prawne i teologiczne składające się na treść kan. 573 dadzą się od siebie odróżnić, ale nie można ich rozdzielać, ponieważ stracą swą tożsamość i znaczenie, które wynikają z ich spójni i ostatecznie definicja życia konsekrowanego okaże się niepełna ${ }^{11}$.

\section{3. Życie konsekrowane przez profesję rad ewangelicznych}

Przed przywołaniem istotnych elementów składowych definicji życia konsekrowanego wydaje się słuszne poświęcenie nieco miejsca samemu terminowi życia konsekrowanego przez profesję rad ewangelicznych, zastosowanego przez prawodawcę w kanonie 573 inicjującym regulację prawną tego stanu w Kościele ${ }^{12}$. Trzeba zaznaczyć, że określenie to odnosi się do zinstytucjonalizowanej formy realizacji rad ewangelicznych, nie zaś do ich praktykowania na sposób uczuciowy, życia tylko ich duchem, do którego zobowiązani są wszyscy chrześcijanie ${ }^{13}$.

\footnotetext{
${ }^{10} \mathrm{KPK} / 1983$, kan. 607; 710, 731, 603, 604.

${ }^{11} \mathrm{D}$. AndRÉs, Le forme di vita consacrata. Commentario teologico-giuridico al Codice di diritto canonico, Roma 2014 ${ }^{7}$, s. 29-30.

${ }^{12}$ KPK/1983, kan. 573.

${ }^{13}$ J.F. Castaño, Significato di vita consacrata..., s. 261.
} 
Od Soboru Trydenckiego profesję rad ewangelicznych składa się w określonym instytucie życia konsekrowanego lub stowarzyszeniu, do których dzięki temu profes jest inkorporowany ze wszystkimi prawami i obowiązkami określonymi precyzyjniej przez prawo własne danego instytutu. Tak więc profesja rad ewangelicznych zgodnie z kan. $654 \mathrm{KPK} / 1983^{14}$ ma wymiar zarówno osobisty - powoduje konsekrację własną osoby przez Boga za pośrednictwem Kościoła, jak i prawny powoduje inkorporację do instytutu, stowarzyszenia lub indywidualnej formy życia konsekrowanego i przyjęcie określonych praw oraz obowiązków. Określenie życie konsekrowane obejmuje zatem oba aspekty profesji, które powinny być rozróżniane, aby nie postrzegano jej tylko jako wcielenia do instytutu $\mathrm{z}$ pominięciem pryncypialnego znaczenia pielęgnowania oblubieńczej relacji z Bogiem. Tę relację KPK/1983 wymienia na pierwszym miejscu w definicji profesji, której jeden ze skutków stanowi konsekracja życia danej osoby Bogu ${ }^{15}$. Ponieważ profesja jest aktem ewangelicznym i eklezjalnym, stąd do swej ważności potrzebuje przyjęcia i zatwierdzenia kompetentnej władzy kościelnej, gdyż tylko wyrażenie przez wiernego wobec Kościoła własnej woli całkowitego poświęcenia się służbie Bogu powoduje odpowiednie skutki teologiczne i prawne.

\section{Elementy teologiczne}

Wśród wymienionych w pierwszej części kanonu 573 elementów teologicznych życia konsekrowanego przez profesję rad ewangelicznych znajdują się: powołanie niektórych wiernych do dokładniejszego naśladowania Chrystusa pod działaniem Ducha Świętego; ich całkowite oddanie się umiłowanemu nade wszystko Bogu; poświęcenie się dla chwały Boga; budowania Kościoła i zbawienia świata z nowego i szczególnego tytułu; dążenie tych osób do osiągnięcia doskonałej

\footnotetext{
${ }^{14}$ KPK/1983, kan. 654.

15 KPK/1983, kan. 654: „Przez profesję zakonną członkowie zobowiązują się publicznym ślubem do zachowania trzech rad ewangelicznych, zostają konsekrowani przez posługę Kościoła Bogu i włączeni do instytutu z prawami i obowiązkami określanymi w prawie".
} 
miłości; konieczność służby Królestwu Bożemu oraz stawanie się w Kościele wyraźnym znakiem i zapowiadanie niebieskiej chwały ${ }^{16}$.

\subsection{Działanie Ducha Świętego}

Początki życia konsekrowanego w Kościele potwierdzają, że zawsze było ono postrzegane jako oblubieńcze przymierze człowieka z Bogiem, zaślubiny z Nim lub jako pakt miłości ${ }^{17}$. Fakt boskiego pochodzenia rad ewangelicznych i sposobu życia według nich przypominają soborowa konstytucja dogmatyczna o Kościele Lumen gentium oraz KPK/1983, gdzie podano, że są one „darem Bożym, który Kościół otrzymał od swego Pana i z Jego łaski ustawicznie zachowuje"18. W ostatnich latach podkreśla się natomiast coraz bardziej rolę Ducha Świętego i trynitarny charakter życia konsekrowanego zauważając, że powołanie każdej osoby do tej konsekracji, u którego początku jest zawsze inicjatywa Ojca, wiąże się bardzo mocno z działaniem Ducha Świętego. To Trzecia Osoba Trójcy Świętej sprawia, że na przestrzeni dziejów wciąż nowe osoby, na wzór uwiedzionego przez Boga Jeremiasza, odkrywają piękno życia konsekrowanego, rozpoznają własne powołanie, wzrastają w nim i dzięki Duchowi Świętemu zdobywają się na pozytywną odpowiedź na nie. Także stopniowa realizacja powołania dzięki praktykowaniu rad ewangelicznych odbywa się pod przewodnictwem Ducha Świętego aż do ostatecznego uformowania się osób konsekrowanych na wzór Chrystusa ${ }^{19}$. Podobnie wielość

\footnotetext{
${ }^{16} \mathrm{KPK} / 1983$, kan. $573 \$ 1$; D. ANDRÉs, Definizione teologico-canonica della vita consacrata per mezzo dei consigli evangelici, w: Tenże, Le innovazioni nel Libro II Parte III del Codice di Diritto Canonico sugli IVC e sulle SVA (cc. 573-746), Vita Consacrata 10(1983), s. 546-547.

${ }^{17}$ V. FAgiolo, Identità teologica e canonica della vita consacrata nella Chiesa, Rivista di Scienze Religiose 7(1993), s. 428-429.

${ }^{18}$ Sobór Waty Kański II, Konstytucja dogmatyczna o Kościele «Lumen gentium», nr 43, w: Sobór Watykański II, Konstytucje, dekrety, deklaracje. Tekst polski. Nowe tłumaczenie, Poznań 2002, s. 104-166 (odtąd LG); KPK/1983, kan. 575.

${ }^{19}$ PC 1, 14; Vita consecrata 19, 14: „Tak więc to szczególne naśladowanie Chrystusa, u którego początków zawsze jest inicjatywa Ojca, ma zasadniczy wymiar chrystologiczny i pneumatologiczny, dzięki czemu wyraża w sposób niezwykle żywy
} 
historycznych form i różnorodność instytutów życia konsekrowanego jest dziełem Ducha Świętego. Ich inicjatorzy i założyciele, obdarowywani Jego charyzmatami, prowadzili życie pustelnicze albo zakładali określone wspólnoty podejmując konkretne cele oraz zadania i obierając określony sposób życia duchowego, odpowiednio do potrzeb Kościoła i świata ${ }^{20}$.

Staje się więc widoczne, że zarówno życie poszczególnych osób powołanych do życia konsekrowanego, jak i całych instytutów jest przeniknięte obecnością i mocą działania Ducha Świętego. A że stan życia według rad ewangelicznych jest znakiem Kościoła-Oblubienicy i stanowi jego część, dzięki niemu Kościół powinien przybierać coraz wyraźniejsze rysy Chrystusa-Oblubieńca, tak aby był święty i nieskalany ${ }^{21}$.

\subsection{Dokładniejsze naśladowanie Chrystusa}

Złożenie profesji rad ewangelicznych zawiera samo w sobie pragnienie naśladowania przez profesów Chrystusa (sequela Christi) w pełnym znaczeniu słowa łacińskiego, tzn. podążania za Nim, kroczenia Jego śladami, nie zaś naśladowania w rozumieniu jedynie imitowania Go, kopiowania, upodabniania się do Niego (imitari) ${ }^{22}$. Aby oddać należyty sposób naśladowania Chrystusa, jaki powinien stać się udziałem osób konsekrowanych, pisze się w dokumentach soborowych o naśladowaniu dokładniejszym, wierniejszym i wyraźniejszym niż czynią to pozostali wierni ${ }^{23}$. Innymi słowy - owo wierniejsze naśladowanie wymaga nie tylko zewnętrznego upodobnienia sposobu życia osoby konsekrowanej do życia Chrystusa, ale przede wszystkim wewnętrznego przeobrażenia się jej aż do odtworzenia w sobie myśli i uczuć Chrystusa, a więc przyjęcia za swoje całego sposobu życia,

\footnotetext{
trynitarny charakter chrześcijańskiego życia”; D. SERI, La presenza attiva dello Spirito Santo nell'anima della religiosa, Rivista delle Religiose, 16(1967), s. 294-298.

${ }^{20}$ PC 1: „Wielu spośród nich, z natchnienia Ducha Świętego, bądź to prowadziło życie pustelnicze, bądź to tworzyło rodziny zakonne"; Vita consecrata 5, 19.

${ }^{21}$ Ef 5, 27; Vita consecrata 19.

${ }^{22}$ Castaño, Significato di vita consacrata..., s. 265-267.

${ }^{23}$ LG 41, 44; PC 1; Vita consecrata 72, 76.
} 
jaki On przyjął, przychodząc na ziemię. Chodzi też o intymną jedność z Nim dotyczącą myśli, woli (Christo coniunguntur), a w końcu o stanie się samym Chrystusem, jak zostało podkreślone w adhortacji apostolskiej Vita consecrata ${ }^{24}$.

Nieodzowność dokładniejszego naśladowania Chrystusa wynika $\mathrm{z}$ profesji trzech rad ewangelicznych ${ }^{25}$ i dotyczy głównie dążenia do przeżywania życia w czystości, ubóstwie i posłuszeństwie, właściwych Chrystusowi, a więc najbardziej radykalnej formy urzeczywistniania Ewangelii na ziemi, formy Boskiej, ponieważ przyjął ją sam Bóg-Człowiek ${ }^{26}$. Jednak osoby konsekrowane należące do różnych instytutów będą zależnie od charyzmatu swojego instytutu nieco odmiennie realizowały owo naśladowanie. Dzieje się tak, ponieważ charyzmaty założycieli instytutów dotyczą tylko niektórych przejawów życia Zbawiciela zawartych w Ewangelii i przekazanych następnie ich uczniom do przeżywania i rozwijania w życiu. Treści charyzmatyczne poszczególnych instytutów, a tym samym zaszczepione określone wartości ewangeliczne, dodatkowo mobilizują ich członków do odzwierciedlenia swym życiem życia Zbawiciela, bo w każdym charyzmacie jest „żar przenikający do głębi duszę, która pragnie się upodobnić do Chrystusa, aby dawać świadectwo o wybranym aspekcie Jego tajemnicy"27.

4.3. Całkowite oddanie się umiłowanemu nade wszystko Bogu

Życie konsekrowane, mimo iż często jest określane mianem sequela Christi, nie polega jedynie na jak najwierniejszym naśladowaniu Go w czystości, ubóstwie i posłuszeństwie woli Ojca aż do śmierci, ale

\footnotetext{
${ }^{24}$ PC 1, 8; Vita consecrata 109: „Nie zapominajcie, że to wy właśnie w bardzo szczególny sposób możecie i powinniście głosić, iż nie tylko należycie do Chrystusa, ale «staliście się Chrystusem»".

${ }^{25}$ PC 2; Vita consecrata 18: „Rady ewangeliczne, poprzez które Chrystus wzywa niektórych, aby dzielili Jego doświadczenie dziewictwa, ubóstwa i posłuszeństwa, wymagają od tego, kto je przyjmuje, zdecydowanej woli całkowitego upodobnienia się do Niego".

${ }^{26}$ Vita consecrata 18.

${ }^{27}$ Vita consecrata 36.
} 
jeszcze bardziej „na przeżywaniu i wyrażaniu swej konsekracji przez poddanie Mu całej egzystencji, które zdecydowanie upodabnia do Niego" ${ }^{28}$. Z jednej strony od osoby obdarzonej powołaniem do życia konsekrowanego Bóg oczekuje odpowiedzi w postaci całkowitego i wyłącznego oddania się Jemu, z drugiej natomiast to doświadczenie głębokiej miłości Boga w momencie powołania niejako przymusza osobę do odpowiedzi bezwarunkowym poświęceniem Mu swego życia, złożeniem w ofierze siebie samego i wszystkiego, co się posiada ${ }^{29}$.

Całkowitość oddania została w konstytucji Lumen gentium określona jako zupełne oddanie się w niewolę (totaliter mancipatur) co upodabnia zakonnika do niewolnika uzależnionego od swego pana ${ }^{30}$. Całkowitość odzwierciedlona w tym pojęciu oznacza nie tylko oddanie uczuć, ale także faktyczną rezygnację z siebie przez wyrzeczenie się trzech największych dóbr człowieka: miłości, dóbr materialnych i wolności. W przypadku zakonników dodatkową konsekwencją całkowitego oddania się Bogu jest przyjęcie warunków życia obcych człowiekowi - oddzielenia od świata zgodnie z charyzmatem instytutu $^{31}$. Także zewnętrzny strój, czyli habit zakonny, powinien świadczyć o całkowitości oddania się i poświęcenia Bogu, co potwierdza soborowy dekret Perfectae caritatis, w którym napisano, że habit jest znakiem konsekracji Bogu ${ }^{32}$.

W KPK/1983 zrezygnowano z użycia słowa mancipatur, a w celu podkreślenia pełni oddania Bogu wobec wszystkich osób konsekrowanych stosuje się określenie „całkowite poświęcenie (totaliter dedicantur) umiłowanemu nade wszystko Bogu”. W przypadku zakonników podkreśla się konieczność poświęcenia całej osoby tak, aby

\footnotetext{
${ }^{28}$ Vita consecrata 16; GAmbari E., Vita religiosa oggi, Roma 1983, s. 83.

${ }^{29}$ Vita consecrata 17.

${ }^{30}$ LG 44: „Deo summe dilecto totaliter mancipatur, ita ut ipse ad Dei servitium eiusque honorem novo et peculiari titulo referatur"; J.F. CASTAÑo, Lo «status consecratorum» nell'attuale legislazione della Chiesa, Angelicum 60(1983), s. 199-206.

${ }^{31}$ KPK/1983, kan. 607; P. Benia mino Della SS. Trinità, Vita religiosa e santità della Chiesa, w: AA.VV., La santità nella costituzione conciliare sulla Chiesa, Roma 1966, s. 175; J.F. CASTAÑo, Significato di vita consacrata..., s. 249.

${ }^{32}$ PC 17.
} 
poświęcenie to stanowiło żertwę ofiarną, pełne złożenie się w ofierze Bogu (holocaustum), jak uzasadniał św. Tomasz z Akwinu ${ }^{33}$. W adhortacji apostolskiej Vita consecrata w nawiązaniu do ofiarniczej myśli św. Tomasza z Akwinu oddającej istotę życia zakonnego aplikuje się konieczność złożenia całopalnej ofiary z życia, a więc całkowitego oddania się Bogu, do wszystkich osób konsekrowanych, a nie tylko zakonników ${ }^{34}$.

Konieczność pełnego oddania przywołuje również istniejącą w Kościele tradycję postrzegania konsekracji monastycznej jako drugiego chrztu dla podkreślenia ponownego zanurzenia się w śmierci Chrystusa, jako wypełnienie się chrztu w aspekcie poświęcenia i jeszcze pełniejszego oddania Bogu w myśl św. Pawła Apostoła „abyście dali ciała swoje na ofiarę żywią, świętą, Bogu przyjemną, jako wyraz waszej rozumnej służby Bożej” (Rz 12,1). Oczywiście stopień „całkowitości” oddania zależy od poszczególnych osób konsekrowanych ${ }^{35}$.

${ }^{33}$ Summa Theologiae II-II, 186 1; KPK/1983, kan. $607 \$ 1$; F. GIARdINI, Lo stato religioso come olocausto, Angelicum 38(1961), s. 187-199.

${ }^{34}$ Summa Theologiae, II-II, q. 186, a. 1; Vita consecrata 17.

${ }^{35}$ Jan Paweł II, Adhortacja apostolska o konsekracji zakonnej w świetle tajemnicy Odkupienia «Redemptionis donum» (25.03.1984), 8, w: Życie konsekrowane w dokumentach Kościoła. Od Vaticanum II do Ripartire da Cristo (red. K. Wójtowicz), Kraków 2003², s. 325-327: „Zanurzając się przez konsekrację ślubów zakonnych w tajemnicy paschalnej Odkupiciela, pragniecie przez miłość całkowitego oddania natchnąć dusze Wasze i ciała duchem ofiary, tak jak Was do tego wzywa św. Paweł słowami Listu do Rzymian, przed chwilą przytoczonymi: „abyście dali ciała swoje na ofiarę". W ten sposób w profesję zakonną wpisuje się podobieństwo tej miłości, która w Sercu Chrystusa jest odkupieńcza i oblubieńcza zarazem. I taka miłość ma w każdym z Was, drodzy Bracia i Siostry, rosnąć z samego źródła owej szczególnej konsekracji, która - na sakramentalnym podłożu Chrztu Świętego - jest początkiem Waszego nowego życia w Chrystusie i Kościele. Początkiem nowego stworzenia"; P. Beniamino della SS. Trinità, Vita religiosa e santità della Chiesa, s. 177; C. PAlmès, Battesimo e vita religiosa, Bologna 1976, s. 59; J. Śliwa, La funzione stabilizzante della Chiesa nel processo di nascita degli IVC - CIC can. 573, s. 108. 
4.4. Poświęcenie się z nowego i szczególnego tytułu dla chwały Boga, budowania Kościoła i zbawienia świata

Na skutek poświęcenia życia Bogu ze szczególnego i nowego tytułu, czyli przez profesję rad ewangelicznych ${ }^{36}$, całe istnienie osoby konsekrowanej staje się nieustającym kultem Boga w miłości ${ }^{37}$. Kult ten w przypadku poszczególnych instytutów życia konsekrowanego i stowarzyszeń życia apostolskiego jest bardzo zróżnicowany i zależy od charyzmatu założycielskiego, na podstawie którego każdy instytut i stowarzyszenie ustala we własnych przepisach sposób korzystania z sakramentów świętych, sprawowania nabożeństw, modlitw, udziału we Mszy świętej oraz innych aktach kultu Bożego. Profesi rad ewangelicznych zobowiązują się także - jak ujmuje to Concilium Vaticanum II i powtarza KPK/1983 - „do miłości bliźniego dla zbawienia świata i budowania Kościoła"38. Innymi słowy, oddają się apostolstwu w różnych jego formach stosownie do charakteru instytutu lub stowarzyszenia - od świadectwa życia konsekrowanego ożywionego modlitwą i pokutą, właściwego wszystkim osobom konsekrowanym, poprzez działalność apostolską (apostolat czynny, zewnętrzny) i dzieła miłosierdzia aż do życia kontemplacyjnego ${ }^{39}$.

\footnotetext{
${ }^{36}$ LG 44: „[wierny - B. Sz.] z nowego i szczególnego tytułu poświęca się służbie Bogu i Jego czci”; M. Conti, La vita consacrata e la sua missione nella Chiesa e nel mondo, Antonianum 68(1993), s. 58, 66; Vita consecrata 30: „W tradycji Kościoła uznaje się profesję zakonną za szczególne i owocne pogłębienie konsekracji chrzcielnej, jako że dzięki niej wewnętrzna jedność z Chrystusem, ustanowiona już przez chrzest, przeradza się w dar upodobnienia do Niego, wyrażony i urzeczywistniony w sposób pełniejszy przez profesję rad ewangelicznych”.

${ }^{37}$ M. Malıński, Katechizm dla niewierzących: „Kult jest to najwyższe uwielbienie składane Bogu przez człowieka lub społeczność. W tym uwielbieniu zawarte jest stwierdzenie różnicy, jaka dzieli stworzenie od Stworzyciela, grzesznika od samej Świętości. Kult jest równocześnie dziękczynieniem za to wszystko, co Bóg uczynił i czyni człowiekowi. Wyrazem tego przeżycia są obrzędy kultyczne”, http://www. opoka.org.pl/biblioteka/K/kat_dla_niel1.html [dostęp 24.09.2015]

${ }^{38}$ PC 6; Por. LG 45; KPK/1983, kan. $573 \$ 2$.

${ }^{39}$ KPK/1983, kan. 673-676; PC 1: „W ten sposób przynagleni miłością, którą Duch Święty rozlał w ich sercach (por. Rz 5,5), coraz bardziej żyją dla Chrystusa i dla Jego Ciała, którym jest Kościół (por. Kol 1,24). Dlatego z im większą gorliwością łączą
} 


\subsection{Dążenie do świętości w służbie Królestwu Bożemu}

Realizacja rad ewangelicznych przez osoby konsekrowane należy nie tylko do istoty życia Kościoła, ale także do jego świętości, ponieważ cel życia osób konsekrowanych jest ściśle związany z celem Kościoła i jego tajemnicą, tj. nieskazitelną świętością otrzymaną od Chrystusa $^{40}$. Wprawdzie wszyscy chrześcijanie zobowiązani są zmierzać do świętości, jednak osoby oddające się całkowicie Bogu przez profesję rad ewangelicznych właśnie z tego szczególnego tytułu ściślej oddają się służbie Bogu, poświęcają się Jego czci i aspirują tym samym do osiągnięcia świętości ${ }^{41}$. I chociaż zmiana nazwy stanu osób poświęconych Bogu przez profesję rad ewangelicznych przesunęła akcent $\mathrm{z}$ ich obowiązku dążenia do doskonałości (status perfectionis) na konsekrację (status consecratorum) ${ }^{42}$, nie zmienia to faktu, że złożona profesja rad ewangelicznych nadal zawiera w sobie obowiązek dążenia do miłości doskonałej i jest wciąż uprzywilejowanym środkiem do jej osiągnięcia ${ }^{43}$.

\subsection{Bycie w Kościele wyraźnym znakiem}

Dokładniejsze naśladowanie Chrystusa nie zamyka się tylko w wymiarze życia wewnętrznego osób konsekrowanych, nie pozostaje czymś intymnym i ukrytym w ich sercach. Przez złożenie profesji nabiera ono wydźwięku publicznego, dzięki czemu osoby te powinny stawać się w Kościele wyraźnym znakiem i zachęcać swym przykładem także innych wiernych do dążenia do świętości bardziej stromą

się z Chrystusem przez takie ofiarowanie siebie samych, które obejmuje całe życie, tym bujniejsze staje się życie Kościoła, a jego praca apostolska tym dorodniejsze wydaje plony".

${ }^{40}$ LG 39, 44; KPK/1983, kan. 207.

${ }^{41}$ LG 47: „Każdy zaś do ślubowania rad ewangelicznych powołany usilnie starać się winien o to, aby wytrwał i wzniósł się wyżej w tym powołaniu, do którego Bóg go wezwał, dla przysporzenia świętości Kościołowi”; LG 44.

${ }^{42}$ KPK/1983, kan. $207 \$ 2,604 \$ 2$; J.F. CASTAÑo, Lo "status consecratorum»..., s. $190-223$.

${ }^{43}$ LG 46; PC 6; G. DE Rosa, Valore ecclesiale ed apostolico della vita religiosa, Rivista delle Religiose, 14(1965), s. 264. 
drogą ${ }^{44}$. Realizacja rad ewangelicznych przez osoby konsekrowane powinna być na tyle uchwytna dla innych ludzi, aby przymioty Jezusa, tj. dziewictwo, ubóstwo i posłuszeństwo, stawały się widzialne w świecie ${ }^{45}$.

Trzeba dodać, że osoby konsekrowane nie mogą ograniczać swego świadectwa tylko do wymiaru trzech rad ewangelicznych, ale w ogóle cały styl ich życia powinien ukazy wać wartości, które wyznają, i stanowić w ten sposób żywy znak Boga i wymowne przepowiadanie Ewangelii ${ }^{46}$. Wartość i siła tego świadectwa są niejako proporcjonalne do stopnia oddania się Bogu przez daną osobę konsekrowaną. W takiej mierze, w jakiej jest ona wierna złożonym ślubom, wyraża jawnie doskonałość swej miłości. Ukazuje się innym jako ktoś, kto oczyma wiary widzi Boga ${ }^{47}$.

W adhortacji apostolskiej Vita consecrata zwraca się uwagę na fakt, że radykalizm tego rodzaju życia nie tylko świadczy o Chrystusie, ale wręcz uobecnia Go w świecie, stanowi historyczną kontynuację szczególnej obecności zmartwychwstałego Pana. Przez powstawanie wciąż nowych form realizacji rad ewangelicznych przypomina Ewangelię otwierającą się w ciągu wieków, jest „jednym z widzialnych śladów, które Trójca Święta pozostawia w historii, aby wzbudzić w ludziach zachwyt pięknem Boga i tęsknotę za Nim"48.

\footnotetext{
${ }^{44}$ LG 13, 31, 42, 44,46, 39: „LG 39: „To praktykowanie rad ewangelicznych, pod wpływem Ducha Świętego podejmowane przez wielu chrześcijan na sposób prywatny albo w warunkach lub stanie ustanowionym przez Kościół, daje i powinno dawać w świecie wspaniałe świadectwo i przykład tej właśnie świętości”; PC 1, 2, $12,13,15,25$.

${ }^{45}$ Vita consecrata 1: „Dzięki profesji rad ewangelicznych charakterystyczne przymioty Jezusa - dziewictwo, ubóstwo i posłuszeństwo - staja się w pewien swoisty i trwały sposób widzialne w świecie, a spojrzenie wiernych zwraca się ku tajemnicy Królestwa Bożego, które już jest obecne w historii, ale w pełni urzeczywistni się w niebie"; Kongregacja Instytutów Życia Konsekrowanego i Stowarzyszeń Życia Apostolskiego, Instrukcja Posługa władzy i posłuszeństwo. Faciem tuam, Domine, requiram 1, Watykan 2008.

${ }^{46}$ Vita consecrata 25,

${ }^{47}$ LG 46; PC 6; Vita consecrata 19, 109.

${ }^{48}$ Vita consecrata 20, por. także 19.
} 
Jeżeli życie konsekrowane spełnia swe zadanie bycia wyraźnym znakiem Chrystusa w Kościele i świecie, podtrzymuje tym samym wśród wierzących i niewierzących świadomość podstawowych wartości Ewangelii, prawdy, że świat nie może się przemienić i ofiarować Bogu bez ducha ewangelicznych błogosławieństw, potwierdza też potrzebę dążenia do świętości jako odpowiedzi na miłość Stwórcy rozlaną przez Ducha Świętego w sercach swych stworzeń. Co więcej - już samo istnienie życia konsekrowanego w Kościele służy konsekracji życia każdego wiernego należącego zarówno do stanu świeckiego, jak i duchownego ${ }^{49}$.

Znaczenie życia konsekrowanego jako znaku jest tak istotne, że „gdyby zabrakło tego konkretnego znaku, należałoby się obawiać, że miłość ożywiająca cały Kościół ostygnie, że zbawczy paradoks Ewangelii straci swą ostrość, że «sól» wiary zwietrzeje w świecie ulegającym sekularyzacji ${ }^{50}$.

\subsection{Zapowiadanie Królestwa Bożego}

Istnieje niezmienne przekonanie, że życie konsekrowane jest także zapowiedzią przyszłego Królestwa, które stanie się udziałem chrześcijan po śmierci, ponieważ konsekracja „w wyższym też stopniu (...) zapowiada przyszłe zmartwychwstanie i chwałę Królestwa niebieskiego" 51 . Osoby konsekrowane, uwalniając się w dużej mierze

\footnotetext{
${ }^{49}$ Vita consecrata 33.

${ }^{50}$ Vita consecrata 105.

${ }^{51}$ LG 44, Vita consecrata 26; G. DE RosA, Valore ecclesiale ed apostolico della vita religiosa, s. 264-265; JAN PAWEŁ II, Życie konsekrowane znakiem i świadectwem Królestwa Chrystusowego (przemówienie Rzym 08.02.1995 r.), http://www.zyciezakonne.pl/1995-02-08-rzym-zycie-konsekrowane-znakiem-i-swiadectwem-krolestwa-chrystusowego-52643/ [dostęp 19.10.2015 r.]: „Rady ewangeliczne mają więc znaczenie eschatologiczne, a konsekrowany celibat zapowiada w sposób szczególny życie w zaświatach i zjednoczenie z Chrystusem Oblubieńcem; ubóstwo zapewnia skarb w niebie; posłuszeństwo otwiera drogę do zdobycia doskonałej wolności dzieci Bożych zgodnie z wolą Ojca niebieskiego. Osoby konsekrowane są więc znakami i świadkami początku życia niebieskiego w życiu ziemskim, które nie może odnaleźć w samym sobie własnej doskonałości, lecz powinno być coraz bardziej ukierunkowane ku życiu wiecznemu: ku przyszłości już obecnej w zarodku, w łasce rodzącej nadzieję".
} 
od spraw ziemskich, powinny intensywniej ukierunkować swoją egzystencję na dobra niebieskie i ukazywać, że Królestwo Boże jest już obecne w zalążku na ziemi ${ }^{52}$. Swym życiem uprzedzają rzeczywistość Królestwa niebieskiego, życia właściwego aniołom - głównie przez ślubowaną czystość - kiedy to po zmartwychwstaniu ludzie nie będą się już żenić ani wychodzić za mąż, lecz będą niczym aniołowie Boży (por. Mt 22, 30) ${ }^{53}$. Wymowa życia konsekrowanego jako znaku eschatologicznego powinna jednoznacznie wskazywać, że jedynym działaniem, naprawdę koniecznym dla chrześcijanina jest poszukiwanie Królestwa Bożego i jego sprawiedliwości, a wtedy wszystko inne zostanie mu dodane (por. Mt 6, 33). Współczesny człowiek mimo swego zeświecczenia jest wciąż wrażliwy na wymowę tego znaku.

\section{Elementy prawne}

Zdefiniowawszy życie konsekrowane pod względem teologicznym, prawodawca podaje $\mathrm{w}$ drugim paragrafie kanonu 573 jego elementy prawne, wyliczając wśród nich: stałość w podjętym sposobie życia; wolność wyboru tego rodzaju życia; zobowiązanie się poprzez śluby lub inne więzy do życia radami ewangelicznymi; szczególną łączność osób konsekrowanych z Kościołem i jego tajemnicą; kanoniczne erygowanie instytutów życia konsekrowanego przez kompetentną władzę Kościoła oraz obowiązek zachowania prawa własnego instytutu.

${ }^{52}$ LG 44: „Stan zakonny, który bardziej uwalnia swych członków od trosk ziemskich, w wyższym też stopniu tak ukazuje wszystkim wierzącym dobra niebiańskie już na tym świecie obecne, jak i daje świadectwo nowemu i wiekuistemu życiu zyskanemu dzięki odkupieniu Chrystusa, jak wreszcie zapowiada przyszłe zmartwychwstanie i chwałę Królestwa niebieskiego. Stan ten naśladuje wiernie i ustawicznie uprzytamnia w Kościele tę formę życia, jaką obrał sobie Syn Boży przyszedłszy na świat, aby uczynić wolę Ojca, i jaką zalecił uczniom, którzy za Nim poszli. Ujawnia on wreszcie w swoisty sposób wyniesienie Królestwa Bożego ponad wszystko co ziemskie oraz jego najważniejsze potrzeby, ukazuje też wszystkim ludziom przeogromną wielkość potęgi Chrystusa królującego i nieograniczoną moc Ducha Świętego działającego przedziwnie w Kościele”.

${ }^{53}$ Vita consecrata 16, 32; Por. Mt 22,30: „lecz będą jak aniołowie Boży w niebie”; C. PALmès, Battesimo e vita religiosa, Bologna 1976, s. 68-76. 


\subsection{Stałość w obranej formie życia}

Rady ewangeliczne są w pełnym tego słowa znaczeniu radami i nie narzucają konieczności zastosowania się do ich wymogów. Jeżeli jednak wierny podejmuje ich realizację przez złożenie profesji, a zwłaszcza profesji wieczystej, zobowiązują one do końca jego życia, a zakonnik po ślubach wieczystych powinien prosić o indult odejścia $\mathrm{z}$ instytutu tylko $\mathrm{z}$ bardzo poważnych przyczyn rozważonych wobec Pana ${ }^{54}$. Jak już wyżej wspomniano, osoba przez akt profesji wchodzi do stanu życia konsekrowanego, a ten z kolei zakłada stały sposób życia - w tym wypadku stały sposób dążenia do doskonałości przez poświęcenie Bogu życia na drodze rad ewangelicznych w określonej strukturze aprobowanej przez władzę kościelną. Stałość życia osoby konsekrowanej jest również konsekwencją jej inkorporacji dzięki złożeniu profesji do stałej struktury kościelnej, jaką są instytuty, stowarzyszenia życia apostolskiego oraz indywidualne i nowe formy życia konsekrowanego. W tym sensie Kościół wykonuje funkcję stabilizacji życia konsekrowanego ${ }^{55}$.

\subsection{Wolność wyboru życia konsekrowanego}

Każda czynność, aby była aktem ludzkim, musi być dokonana w wolności ${ }^{56}$. Stąd zgodnie z kanonem 125 KPK/1983 czynność dokonaną pod wpływem przymusu zewnętrznego wywartego na osobę, która nie mogła mu się oprzeć, uważa się za niedokonaną. Natomiast czynność dokonaną pod wpływem ciężkiej, nieusprawiedliwionej bojaźni, a więc przymusu moralnego, zasadniczo uważa się za ważną, chyba że prawo wyraźnie stanowi co innego. Odnosząc wspomnianą normę prawną do życia konsekrowanego, należy stwierdzić, że prawo uznaje za nieważne, przyjęcie kandydatów do nowicjatu oraz złożenie

\footnotetext{
${ }^{54} \mathrm{KPK} / 1983$, kan. $691 \$ 1$.

${ }^{55}$ J. Śliwa, La funzione stabilizzante della Chiesa nel processo di nascita degli IVC - CIC can. 573, s. 108-109.

${ }^{56}$ P. Lombardía, Księga I. Normy ogólne, w: Kodeks Prawa Kanonicznego. Komentarz, red. P. Majer, Kraków 2011, s. 147-148.
} 
profesji czasowej lub wieczystej, jeżeli miały miejsce przymus, bojaźń lub podstęp ${ }^{57}$.

5.3. Zobowiązanie się do życia radami ewangelicznymi przez śluby lub inne więzy

W dokumentach soborowych i posoborowych stwierdza się, że życie konsekrowane i wyrasta $\mathrm{z}$ profesji rad ewangelicznych, które biorą początek z nauczania, przykładu życia i działania Boskiego Mistrza. Wymienione dokumenty podają także definicje trzech rad ewangelicznych: czystości, ubóstwa i posłuszeństwa zarówno w wymiarze teologicznym, jak i prawnym ${ }^{58}$. Ich myśl przewodnia jest ogólnie znana i często bywa podejmowana w ramach badań naukowych, stąd w kontekście tematu niniejszego studium zostanie pominięta ze względu na jego ograniczoną objętość. Warto natomiast przypomnieć ważną kwestię, którą rzadko można spotkać w literaturze przedmiotu, a tylko wyjątkowo w formacji osób konsekrowanych: chociaż rady ewangeliczne są podstawą życia konsekrowanego, to jednak nie czynią one jego istoty ${ }^{59}$. Chrześcijanin już przez chrzest umiera dla grzechu i jest poświęcony, czyli konsekrowany Bogu, natomiast profesja jako foedus - przymierze, związek jest tylko nowym i szczególnym tytułem całkowitego poświęcenia się osoby konsekrowanej już przez chrzest na służbę Bogu i Jego czci (kultowi), aby mogła otrzymać jeszcze obfitsze owoce łaski chrztu ${ }^{60}$. Początkom życia monastycznego triada rad nie była znana. Pojawiła się ona dopiero w XII-XIII wieku. Wcześniej wierni pragnący konsekrować się na służbę Bogu wyrażali wolę kształtowania swego życia w oparciu o przykład samego Chrystusa: czystego, ubogiego i posłusznego woli Ojca, zawierając umowę, układ nazywany foedus, sanctum propositum, votum religionis ${ }^{61}$.

\footnotetext{
${ }^{57}$ KPK/1983/kan. 643, 656.

${ }^{58}$ LG 43, 44; PC 12-14; KPK/1983, kan. 575, 599-601; Vita consecrata 22.

${ }^{59}$ M. Conti, La vita consacrata e la sua missione..., s. 70.

${ }^{60}$ TAMżE; LG 44.

${ }^{61}$ M. Conti, La vita consacrata e la sua missione..., s. 70, 71; M. Conti, Voti religiosi e alleanza sponsale nella vita consacrata, Antonianum 63(1988), s. 167; J.M.R. Tillard, Consigli evangelici, DIP, v. II, Roma 1975, kol. 1653-1656.
} 
Tak więc istoty życia konsekrowanego nie należy doszukiwać się w radach ewangelicznych, na które w codzienności życia konsekrowanego kładzie się obecnie duży nacisk, lecz w uprzedzającym je oblubieńczym zjednoczeniu z Chrystusem, przymierzu miłości i byciu z Nim, dzieleniu Jego życia (Mk 3,14), z których to relacji wynika dopiero w dalszej konsekwencji realizacja rad. Ostatnie dokumenty kościelne próbują przeinterpretować znaczenie pozycji rad ewangelicznych przypominając, że ich fundamentem jest nie tyle życie pierwszej wspólnoty zgromadzonej wokół Chrystusa, ile specyficzna relacja, jaką nawiązał On ze swoimi uczniami w ich doświadczeniu pełnego zjednoczenia $\mathrm{z} \mathrm{Nim}^{62}$.

Zobowiązanie do życia radami ewangelicznymi osoba konsekrowana wyraża w czasie profesji przez śluby lub inne więzy. Ślub jest uczynioną Bogu obietnicą wykonania dobra możliwego i lepszego ${ }^{63}$, czyli w tym wypadku szczególnego naśladowania Chrystusa czystego, ubogiego i posłusznego woli Ojca, w jednym z instytutów kanonicznie erygowanych. Innymi oprócz ślubów więzami mogą być: przysięga, przyrzeczenie, obietnica, przyrzeczenia itp., które stanowią umowę zawartą $\mathrm{z}$ instytutem lub stowarzyszeniem.

\subsection{Szczególna łączność z Kościołem i jego tajemnicą}

Sobór Watykański II jak żaden z wcześniejszych soborów poświęcił dużo uwagi łączności życia konsekrowanego z tajemnicą Kościoła. Pod wpływem teologicznej refleksji nad naturą stanu dążenia do doskonałości Sobór stwierdził m.in., że należy on do życia i świętości Kościoła, i przełamał dotychczasowe wyobrażenia, że jest on tylko dodatkiem do Kościoła, jakąś nadbudową czy stanem pośrednim między laikatem a duchowieństwem. Dzięki swojej oblubieńczej naturze należy do samego serca Kościoła i ma duże znaczenie dla jego misji, ponieważ ukazuje dążenie Kościoła-Oblubienicy do zjednoczenia

\footnotetext{
${ }^{62}$ Vita consecrata 14,41

${ }^{63}$ KPK/1983, kan. 1191.
} 
ze swym Oblubieńcem ${ }^{64}$. Z kart Nowego Testamentu wynika, że wizja Kościoła złożonego jedynie z wiernych świeckich i duchownych nie wyrażała w pełni zamiaru Chrystusa - jego założyciela ${ }^{65}$, ale do pełnego obrazu Kościoła były niezbędne osoby, które mogą pojąć fragmenty Ewangelii dotyczące życia w czystości, ubóstwie i posłuszeństwie, niezrozumiałe dla innych słuchaczy. Oznacza to, że bez osób konsekrowanych Kościół nie byłby nim w pełni, ponieważ nie żyłby pełnią tajemnicy życia Chrystusa i nie ukazywałby światu całego światła Ewangelii ${ }^{66}$. Stąd wnioskuje się, że „życie konsekrowane, obecne w Kościele od samego początku, nigdy nie zaniknie jako jego niezbywalny i konstytutywny element, ponieważ wyraża samą jego naturę"67.

Na inny rodzaj łączności z Kościołem wskazuje charyzmatyczny charakter życia konsekrowanego. Nie odnosi się ono bowiem do hierarchicznej struktury Kościoła, lecz ma takie samo znaczenie dla wspólnoty Ludu Bożego, jakie dusza dla ciała - obie struktury, przenikając się wzajemnie, tworzą nierozłącznie jeden byt. Charyzmat przekazuje informacje hierarchii, a ta nie istnieje, jeżeli nie jest ożywiana przez charyzmat ${ }^{68}$. W tej perspektywie charyzmaty poszczególnych instytutów i ich założycieli, wzbudzane przez Ducha Świętego - podobnie jak wszystkie inne charyzmaty w Kościele - co do swej autentyczności podlegają osądowi hierarchii kościelnej ${ }^{69}$. Życie konsekrowane rodzi się więc i rozwija w ścisłej zależności od

${ }^{64}$ LG 46: „[Osoby konsekrowane - B. Sz.] przez wytrwałą i pokorną wierność wymienionej konsekracji stają się chlubą Oblubienicy Chrystusa i wszystkim ludziom świadczą szlachetne i rozliczne posługi”; PC 1b, 12; Vita cosecrata 3, 105; J.F. CAstAÑo, Il contesto ecclesiale della vita consacrata, w: AA.VV., Il nuovo diritto dei religiosi, Roma 1984, s. 42, 47; J. F. CASTAGÑo, Significato di vita consacrata..., s. 275.

${ }^{65}$ Vita consecrata 29.

${ }^{66}$ LG 44: „Choć więc stan, który opiera się na profesji rad ewangelicznych, nie dotyczy hierarchicznej struktury Kościoła, należy on jednak nienaruszalnie do jego życia i świętości”; G. DE RosA, Valore ecclesiale ed apostolica della vita religiosa, s. 263-265.

${ }^{67}$ Vita consecrata 29.

${ }^{68}$ J. F. CAstaño, Significato di vita consacrata..., s. 273.

${ }^{69}$ LG 45; PC 1. 
władzy kościelnej. Także każda osoba podejmująca rady ewangeliczne w szczególny sposób łączy się z Kościołem, gdyż za pośrednictwem właściwych przełożonych potwierdza on i ogłasza autentyczność powołania osobistego danej osoby, przyjmując ją do określonego instytutu, a następnie potwierdza złożenie profesji i związaną z nią konsekrację, co stanowi główny rys życia konsekrowanego ${ }^{70}$. W obrzędzie profesji Kościól jest obecny nie tylko w aspekcie prawnym, ale także liturgicznym ${ }^{71}$. W czasie tego obrzędu Kościół modli się o dar Ducha Świętego dla powołanych osób i łączy ich ofiarę z ofiarą Chrystusa. Także następujący po tym cały proces realizacji rad ewangelicznych prowadzi do głębszej relacji z Bogiem, do gorliwszej służby bliźnim, działalności apostolskiej, modlitwy itp. Wszystkie te środki mają charakter eklezjalny, należą do misji Kościoła i są wyrazem służby Bogu, Chrystusowi i Jego Kościołowi ${ }^{72}$. Innymi słowy, stan życia konsekrowanego prowadzi nie tylko do osobistego uświęcenia wiernych do niego przynależących, ale służy też Kościołowi, przyczyniając się do jego świętości. Prawdę tę wyraził Sobór Watykański II w konstytucji dogmatycznej o Kościele Lumen gentium: „Ponieważ rady ewangeliczne przez miłość, do której prowadzą, w szczególny sposób łączą z Kościołem i jego misterium tych, którzy je zachowują, dlatego ich duchowe życie powinno być poświęcone także dobru całego Kościoła"73.

${ }^{70}$ LG 45: „Kościół zaś nie tylko podnosi swym zatwierdzeniem profesję zakonną do godności stanu kanonicznego, ale także przez działalność liturgiczną ukazuje ją jako stan poświęcony Bogu. Na mocy bowiem władzy udzielonej mu przez Boga Kościół przyjmuje śluby od tych, którzy je składają, swą publiczną modlitwą wyprasza im pomoc i łaskę u Boga, poleca ich Bogu i udziela im duchowego błogosławieństwa, łącząc ich ofiarę z Ofiarą eucharystyczną”; PC 5: „Ponieważ zaś to ofiarowanie siebie samego zostało przyjęte przez Kościół, zakonnicy winni być świadomi tego, że oddali się również na jego służbę".

${ }^{71}$ LG 45.

${ }^{72}$ PC 6; P. Beniamino della SS. Trinità, Vita religiosa e santità della Chiesa, w: AA.VV., La santità nella costituzione conciliare sulla Chiesa, Roma 1966, s. 186.

${ }^{73}$ LG 44; PAweE VI, Przemówienie In questo giorno, 2 luty 1972, AAS 64 (1972) 206 212; VC 8 (1972) 81-87; tekst polski w: Charyzmat życia zakonnego. Przemówienia 
5.5. Kanoniczne erygowanie instytutów życia konsekrowanego

Nie tylko indywidualny akt profesji wiernych obdarzonych łaską powołania do praktykowania rad ewangelicznych jest aktem eklezjalnym, czyli przyjmowanym w imieniu Kościoła przez odpowiednią władzę. Jest nim również zatwierdzenie przez kompetentną władzę kościelną zorganizowanej wspólnoty osób konsekrowanych po stwierdzeniu autentyczności jej charyzmatu. Życie konsekrowane jako rzeczywistość charyzmatyczna przyjmuje ciało - rodzi się i rozwija w historycznym kontekście Kościoła lokalnego. Organizuje się w ramach instytutów, stowarzyszeń życia apostolskiego oraz indywidualnych i nowych form, które należą do wymiaru społecznego Kościoła jako Ludu Bożego i dlatego muszą być zatwierdzane odpowiednim aktem prawnym przez właściwą władzę kościelną ${ }^{74}$.

Trzeba też zauważyć, że całe życie chrześcijańskie oparte na sakramencie chrztu Chrystus powierzył trosce Apostołów i ich następców. Podobnie też i życie konsekrowane wynikające z profesji rad ewangelicznych, nieodłącznie związane z Kościołem, stanowi przedmiot troski następców Apostołów ${ }^{75}$. Biskup diecezjalny, będący wikariuszem Chrystusa w Kościele lokalnym, towarzyszy powstawaniu instytutu życia konsekrowanego i go zatwierdza ${ }^{76}$.

i dokumenty. Wybór i opracowanie A. Żuchowski, T. Sułowska, Poznań-Warszawa 1974, s. 171.

${ }^{74}$ M. Conti, La vita consacrata e la sua missione..., s. 60; J. ŚLIwA, La funzione stabilizzante della Chiesa nel processo di nascita degli IVC-CIC can. 573, s. 103.

${ }^{75}$ M. Conti, La vita consacrata e la sua missione..., s. 57; LG 45: „Ponieważ zadaniem hierarchii kościelnej jest pasienie Ludu Bożego i prowadzenie go na jak najobfitsze pastwiska (por. Ez 34,14), do niej także należy mądre kierowanie przez ustawy praktyką rad ewangelicznych... Hierarchia również, podążając z uległością za natchnieniem Ducha Świętego, przyjmuje reguły przedłożone przez znakomitych mężczyzn i kobiety, a następnie dokładniej uporządkowane zatwierdza; swoim czujnym i pomocnym autorytetem wspiera instytuty ustanowione w różnych miejscach celem budowania Ciała Chrystusa, aby wzrastały i rozwijały się w duchu założycieli”; KPK/1983, kan. 574, 576, 589-595, 605.

${ }^{76}$ KPK/1983, kan. 579. 


\subsection{Przestrzeganie prawa własnego instytutu}

Każdy instytut posiada tzw. prawo własne w postaci kodeksu fundamentalnego, nazywanego najczęściej konstytucjami, oraz innych drugorzędnych zbiorów prawnych - dyrektoriów, reguł, ustaw, typików itp. Przepisy tychże zbiorów - również zatwierdzone przez odpowiednią władzę kościelną - odzwierciedlają charyzmat założyciela i charyzmat instytutu, czyli dar Ducha Świętego dany członkom instytutu do budowania Mistycznego Ciała Chrystusa ${ }^{77}$. Prawo własne jest jednocześnie zarówno dla całej wspólnoty instytutu, jak i poszczególnych jego członków programem kształtowania własnego stylu życia na wzór życia Chrystusa ${ }^{78}$.

Aby w sposób zamierzony przez Ducha Świętego włączyć się w budowanie Kościoła, dążyć do doskonałości, być wyraźnym znakiem Chrystusa i Go uobecniać w świecie, osoba konsekrowana powinna wiernie zachowywać prawo własne instytutu oddające charyzmat założycielski i pozwalające gorliwiej przeżywać istotne elementy życia konsekrowanego, wymienione w niniejszym studium ${ }^{79}$. Ścisłe stosowanie się do przepisów prawa własnego służy także osobom konsekrowanym pomocą w znalezieniu właściwych form dawania świadectwa odpowiednio do zmieniających się potrzeb społeczeństwa i Kościoła ${ }^{80}$.

\section{Zakończenie}

Spośród wszystkich wiernych w Kościele katolickim, konsekrowanych Bogu przez sakrament chrztu świętego i zobowiązanych na tej podstawie do zachowania Dekalogu, a więc tego, co „konieczne”, wyróżniają się wierni konsekrowani dodatkowo przez profesję triady rad ewangelicznych, która sięga swymi korzeniami konsekracji chrzcielnej i pełniej ją wyraża. Na podstawie drugiej, specjalnej konsekracji zobowiązują się oni dodatkowo do tego, co „lepsze”, tzn.

\footnotetext{
${ }^{77}$ PC 8; KPK/1983, kan. 577.

${ }^{78}$ LG 46.

${ }^{79}$ Vita consecrata 36.

${ }^{80}$ Vita consecrata 36, 37.
} 
życia w czystości, ubóstwie i posłuszeństwie ewangelicznym na wzór Chrystusa ubogiego, czystego i posłusznego woli Ojca aż do śmierci ${ }^{81}$. Ich sposobu życia nie da się określić w jednym zdaniu i stąd prawodawca kościelny definiuje go w kilku kanonach KPK/1983.

\section{Juridical-theological definition of the consecrated life by profession of the evangelical counsels}

The term consecrated life appeared quite recently. Though it is commonly used, and yet - as it seems - it is not understand to the full extend even by the very persons to whom it refers. That's because not many of them read the John Paul's II Canonical Law Code of 1983, where there is given a full definition of the consecrated life. The term is usually explained as the life particularly sacrificed (consecrated) to God. At the same time sacrament of baptism - called also by the term of baptismal consecration - already dedicates the life of each baptized to God, so it becomes a true consecrated life. Likewise a priest by reception of the consecration sacrament simultaneously sacrifices himself to God. What kind of consecration then we are talking about in the case of so called consecrated persons? When it takes place, and what so much distinguishes the consecrated persons, that they create separate class in the Church, though it is not a hierarchic one? The answers for such questions are given in the article, which analyses the Code's definition of the consecrated life, and its forms existing in the Catholic Church.

SŁowA KLUCzowe: definicja, stan doskonałości, życie konsekrowane, elementy teologiczne, elementy prawne.

Key Words: definition, state of perfection, consecrated life, theological elements, juridical elements.

\section{Nota o Autorze:}

S. DR hab. Bożena Szewczul WNO, prof. UKSW - profesor nadzwyczajny na Wydziale Prawa Kanonicznego UKSW w Warszawie, kierownik zakładu Kanonicznych Forma Życia Konsekrowanego w katedrze Ustroju Kościoła i Kanonicznych Form Życia Konsekrowanego.

\footnotetext{
${ }^{81}$ Redemptionis donum 9, Vita consecrata 31.
} 